\title{
メタノール燃料電池の空気極水バランスの シミュレーションと性能安定化の検討
}

\author{
正員 津久井勤 (日 立) \\ 非会員 朝 日 聖 隆 (日立機社エンジニアリンタ)
}

\section{Simulation of Water Balance at Cathode and Stabilization of Power for Methanol Fuel Cells}

Tsutomu Tsukui, Member (Hitachi, Ltd.), Kiyotaka Asahi, Non-member (Hitachi Machinery \& Engineering, Ltd.)

On the methanol fuel cell which uses methanol as fuel directly, the important problem to keep high efficient and stable operation is to exhaust water generated in air electrode appropriately and to keep the best water balance without over wetting or drying in air electrode. Therefore, the theoretical equations were introduced to consider the relation between generated water by electrochemical reaction and exhausted water by the flowing air along the air flow direction.

By using these equations, simulation on various conditions of operation and structure were made. As a result, the countermeasure to keep best water balance was found as follows.

(1) The increasing of water reservation in air electrode with thicker electrode and the increasing of hydrophilic ability by addition of electrolyte were effective and applicable methods for practical use.

(2) The reduction of water permeability in electorolyte layer is effective, which was attained by the system with solid polymer electrolyte and without sulfuric acid.

(3) Larger air chamber depth and appropriate humidity control of inlet air are effective. However, these methods are limited to use because of the increasing of size and flow-rate.

キーワード：メタノール燃料電池, 空気極, 水バランス, 性能安定化, 電解質, 空気流路

\section{1.まえがき}

直接型メタノール-空気燃料電池 (以下, メ夕)ー 几燃料電池と略記）は，常温作動で然料が液体である ことから扱いが容易なため, 中小形ポータブル電源と して研究開発が行われている(1)(2)。

この燃料電池の高効率高出力で安定な運転にとって 重要なことは，（i）燃料の余分な消費量を抑えて高い 燃料利用率を維持すること, (ii) 空気極で生成する水 分を効果的に排出して，濡れ過ぎや乾きのない良好な 水バランスを維持することである。

(i) 高い燃料利用率を維持するためには，燃料供給
系側においてメタノール極に供給するメタノール濃度 を一定䉇囲内に制御することと,メ夕ノール透過係数 の小さいイオン交換膜を電解質として使用するこ と(3)(4)である。イオン交換膜のメタノール透過係数の 小さい活うが望ましいが，電気抵抗が高くなるので限 度がある。従って,メタノール濃度のきめ細かい制御 が必要となる。

次に，(ii）空気極の水バランスを良好に保つことで あるが，空気極では次の水分の生成と排出がある。ま ず，空気極では発電に伴う生成水とメタノール極から 電解質層を通して移動してきたメタノールと水分があ り，このメタノールが空気極で直接酸化して水分を生 
成する。これら空気極の水分を空気室へ送風する空気 中に蒸発させて，燃料電池外へ排出することとなる。 従って,この空気極の水分を送風空気によって過不足 なく排出して，水バランスを良好に保つことがなによ りも大切である。そのため，この空気極の水分量を送 風空気流量との関係において理論的に導き出し, 水バ ランスを好適に保つ方法を提案した (5)。

しかしながら，上記の方法は電極が一点に集中した 状況での解析であった。ところが実際には電極が面積 をもっており，空気の送風にも方向性をもっているの で, 架気極内で水分の生成が同じであるとみなして も，空気室の空気の入口付近と出口付近では水分の蒸 発量が違ってくると考えられる。そのため, 空気室内 の空気の流路方向に空気極では水分の分布が生じる。 燃料電池の空気極の水バランスを更に好適に保ち, 安 定な性能を維持するためには，この空気流路に沿った 水バランスを考慮した解析が必要となる。

本論文は, 上記空気極内の空気流路方向の水バラン スについての解析を行って，好適な性能を維持するた めの諸条件を検討した結果について述べている。

\section{2. メタノール燃料電池の原理と空気室内蒸発} 可能水分量の理論式誘導

〈2・1〉メタノール燃料電池の原理と性能安定化の 指針

（1）メタノール燃料電池の原理 メタノール燃 料電池の原理図を図 1 に示したが, 電解質層を介して 触媒の添着されたメタノール極と空気極が配置され る。電解質層は, 希硫酸とイオン交換膜の插入された 構成である。イオン交換膜の機能は, 電子伝導性を阻 止し良好なイオン導電性と燃料がメタノ一儿極から空 気極に浸透するのを防止する機能を有している。とこ ろで,メタノール極には燃料であるメ夕ノールを供給

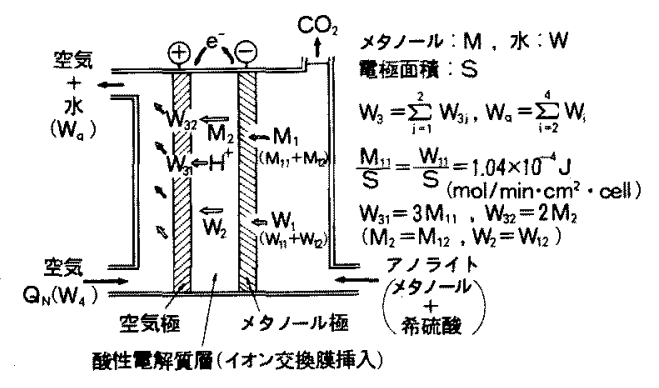

×夕ルール梗 $\ominus: \mathrm{CH}_{3} \mathrm{OH}+\mathrm{H}_{2} \mathrm{O} \Rightarrow \mathrm{CO}_{2}+6 \mathrm{H}^{+}+6 \mathrm{e}^{-}$

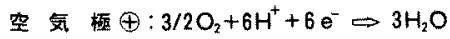

図 1 メ夕ノー儿燃料電池の原理図

Fig. 1. Formation of methanol fuel cell.
するが，電解質として希硫酸を用いていることもあっ て，これが燃料供給系側に流出するのを防止する意味 で，あらかじめメタノールと希硫酸の混合液（アノラ イト）として供給している。このとき，メタノール極 では触媒反応によってメタノールの酸化反応が行わ れ，メ夕ノ一ル $M_{11}$ と水分 $W_{11}$ が消費される。同時 に, 電解質層を浸透するメ夕ノール $M_{2}$ と水 $W_{2}$ があ り,メタノール極ではメタノール $M_{1}$ と水 $W_{1}$ が消費 される。

一方, 空気極には空気流量 $Q_{N}$ (空気中の水分 $\left.W_{4}\right)$ が供給され，電気化学反応によって生ずる生成水 $W_{31}$ と浸透メ夕ノール $M_{2}$ の空気極での直接酸化による生 成水 $W_{32}$, ならびに浸透水 $W_{2}$ を蒸発させて空気室外 に排出される。従って，空気流量 $Q_{N}$ は図 1 に示す空 気極反応に必要な酸素の供給と同時に空気極の水分を 蒸発させるのに必要な量をとることになる。なお，各 極に扮ける電気化学反応式ならびにその反応によって 消費するメタノール $M_{11}$ と水分 $W_{11}$ の量, ならびに 空気極に扔计る生成水 $W_{3}\left(=W_{31}+W_{32}\right)$ は图 1 亿示 した関係にある。また, 空気極生成水 $W_{3}$ は燃料利用 率 $\eta_{e}$ との関倸に扔いて図2のように示される。

（2）性能安定化の指針 図1に扔いて, 性能安 定化に大きく寄与しているのは緒言でも述べたよう に, 空気極の水バランスがいかに効果的に保たれるか にかかっている。すなわち，空気極における水分を過 不足なく供給し, 笁気中に蒸発させることができるか ということである。

燃料電池における空気極での水バランスに関係した

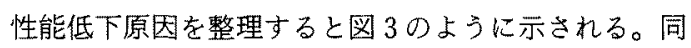
図に示したように，運転条件を誤まると水バランスか らの不平衡が生じ，（i）または(iii)の条件になると性 能が低下すると考えられる。このような図 3 に示した

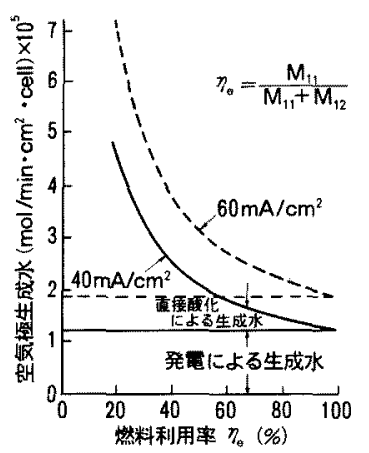

図 2 燃料利用率と空気極生成水

Fig. 2. Relationships between fuel efficiency and generated water in cathode. 
(i)

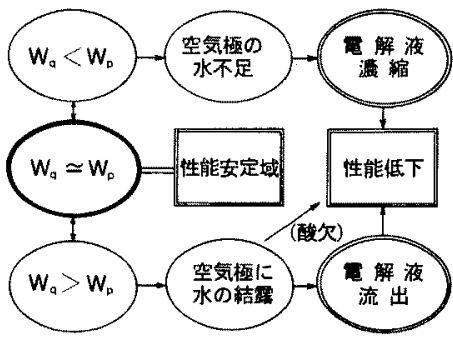

$W_{p}$ : 空気室出口での蒸発可能水行嘿, $W_{q}=\sum_{i=2}^{q} W_{i}$ (図1参照)

図 3 燃料電池の性能低下要因

Fig. 3. Factors of performance decrease on fuel cell.

燃料電池における三つの状態が, 単セルの空気極内で も空気室の送風空気の入口側から出口側に向かって (i ) $\rightarrow$ (iii) の順序で見られ，この不平衡を緩和するこ とが性能安定化にとって不可欠となる。そのため，空 気室内の空気流路方向 $x$ に対して蒸発可能水分量を シミュレートし，空気極水分量との関係で性能安定性 を検討した。更に，この結果を基に空気極内での水心゙ ランスからの不平衡を緩和する方法について考察し た。

〈2・2〉 空気室内蒸発可能水分量についての理論式 誘導空気極に隣接した空気室の送風空気入口から $x$ の位置に $d x$ の微小容積を考文, この中の空気中の 水蒸気の濃度を $C_{x}$ とする。この微小容積中を空気が 通過する間に空気中に增加した水蒸気の量が，その間 に蒸発した水蒸気の量に等しいという物質収支を考え る(6)。この仮定のもとに誘導した空気中の水蒸気の濃 度 $C_{x}$ は先に報告したように测式のように示さ れる。

$$
C_{x}=C_{s}\left\{1-\left(1-\frac{C_{0}}{C_{s}}\right) \exp (-Z)\right\}
$$

ここに, $C_{0}: x=0$ における $C_{x}$ の值, $C_{S}$ : 空気室内飽和水蒸気濃度, $C_{0} / C_{S}, C_{x} / C_{S}$ ： れぞれ空気室入口と空気室内での相刘湿度

また， $Z$ は次式で示される。

$$
Z=\frac{A}{Q_{N}}\left[L_{x}-B\left\{Q_{N}\left(C_{x}-C_{0}\right)-\frac{W_{3}}{S} L_{x}\right\}\right]
$$

ここに, $S:$ 電極面積, $L:$ 空気室の横幅, $A:$ 物質移動係数 ${ }^{(6)}$ に比例する定数, $B:$ 電 解質層の水浸透抵抗に逆比例寸る定数

このうち，A は実験式が得られて拈り，層流の場 合には次のように表される(7)。

$$
A=\alpha \cdot \operatorname{Re}^{0.5} \cdot \operatorname{Pr}^{0.33} D_{a} / d
$$

ここに, Re：レイノズル数, $\operatorname{Pr}:$ プランク

卜ル数, $D_{a}$ : 水蒸気の㹡散係数, $d:$ 空気室

奥行, $\alpha:$ 定数

また, $Q_{N} C_{x}=W(x), Q_{N} C_{s}=W_{s}$ (最大蒸発可能水 分量), $Q_{N} C_{0}=W_{4}$ (供給空気中の水分量) であり, 定 数 $A$ は (4)式のように示されるので, (2)式は (5) 式のように表される。

$$
\begin{aligned}
& A=k\left(Q_{N} / L\right)^{0.5} \cdot 1 / d \\
& W(x)=W_{s}\left\{1-\left(1-\frac{W_{4}}{W_{S}}\right) \exp (-Z)\right\}
\end{aligned}
$$

ここに, $Z$ は次式で表される。

$$
Z=k\left(\frac{L}{Q_{N}}\right)^{0.5} \frac{x}{d}\left\{1-B\left(\frac{W(x)-W_{4}}{L_{x}}-\frac{W_{3}}{S}\right)\right\}
$$

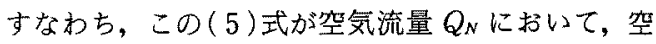
気室内の $x$ 点での空気極からの蒸発可能水分量 $W(x)$ を示すことになる。

\section{〈2・3〉空気極水バランスと性能安定化との対応}

一つのセルの空気極内で図 3 に示した 3 段階の変化 が見られると予想したが，このことを前節の $(5)$ 式を 使って以下に述べる。

図 4 (a) は空気室内流路方向 $x$ に対して, $W(x)$ と $W_{3}$ をデル的に示したものである。空気極ではどの 場所でも単位面積当たりの生成水量 $W_{3}$ が同じとみ て, 図 5 (a)上では $x$ に比例する。これに対して, $W(x)$ は架気流量 $Q_{N}$ によって変わり， $x$ の增加と共 に飽和の傾向にある。そこで，空気極幅方向の分布は ないとみなして， $x$ 方向に対して $d W(x) / d x$ をとる 々, この值は $x$ に抢ける水蒸発可能速さに関係した 值となる。この $d W(x) / d x$ は次式のように示される。

$$
\begin{aligned}
\frac{d W(x)}{d x}= & k\left(\frac{L}{Q_{N}}\right)^{0.5} \frac{W_{S}}{d}\left(1-\frac{W_{4}}{W_{s}}\right)\left\{\left(1+\frac{W_{3}}{S}\right)\right. \\
& \left.-\frac{B}{L} \frac{d W(x)}{d x}\right\} \exp (-Z) \cdots \cdots(7) \\
\frac{d W(x)}{d x}= & \frac{1+W_{3} / S}{\frac{B}{L}+\frac{1}{k\left(L / Q_{N}\right)^{0.5}(1 / d)\left\{W_{S}-W(x)\right\}}}
\end{aligned}
$$

$$
\begin{aligned}
& \text { これより, } B=0 \text { のとき } \\
& \frac{d W(x)}{d x}=k\left(\frac{L}{Q_{N}}\right)^{0.5} \frac{1}{d}\left(1+\frac{W_{3}}{S}\right)\left\{W_{s}-W(x)\right\}
\end{aligned}
$$

そこで, 図 4(a) に対応して $d W(x) / d x$ を示すと (b)図のようになる。ここでは，空気極生成水分量は 単位面積当たりどこでも同じとしているので， $B=0$ とみなして $d W_{3} / d x$ を示すと一点鎖線のようにフラッ 


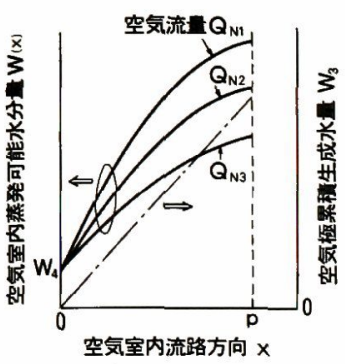

(a) $x \sim W(x)$

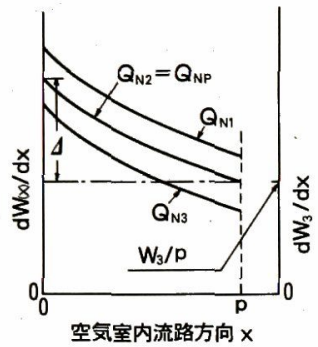

(b) $x \sim d W(x) / d x, d W_{3} / d x$
図 4 空気室内空気中水分量の

シミュレーションモデル図

Fig. 4. Simulation model of water in air of air chamber.

トになる（ $B$ を変数として取扱う折には，後述のよ うに空気極の生成水分量は一定として, $W(x)$ の計算 のほうで考慮した)。(b)図から，曲線 $d W(x) / d x$ が $d W_{3} / d x$ より大きい領域では, 図 3 に示した（i )の条 件が見られ, 空気流量 $Q_{N 3}$ の場合でみると $x$ が大き くなる（空気室出口に近づく）と共に順次（ii）から (iii)の条件が見られることになる。

性能安定化には空気極の水バランスを保つことが必

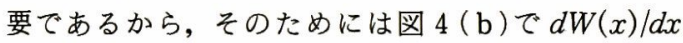
と $d W_{3} / d x$ の差は小さくすることである。そこで便宜 上 $\Delta を(10)$ 式のように定義すると，この $\Delta$ をさく することが性能安定化にとって必要条件となる。

$$
\Delta=\left.\frac{d W(x)}{d x}\right|_{x=0}-\left.\frac{d W(x)}{d x}\right|_{x=p}
$$

ここに, $p:$ 空気極高さ方向の寸法

$B=0$ のとき

$$
\Delta=\frac{k}{d}\left(\frac{L}{Q_{N}}\right)^{0.5}\left(1+\frac{W_{3}}{S}\right)\left(W_{P}-W_{4}\right)
$$

ところで, 次章で述べるシミュレーション結果の整 理方法として, この $\Delta$ と $d W(x) /\left.d x\right|_{x=p}=W / P$ の場 合の $Q_{N}$ [図 $4(\mathrm{~b})$ では $Q_{N_{2}}$ に相当]を $Q_{N P}$ と定義した 值とで示す。

以上述べてきたところから， $\Delta$ をさくする方法と して, 詳細は後述するが，（8），(11)式よりLを小 さくする,$d や W_{4}$ を大きくする， $B$ を大きくするこ となどが考えられる。

\section{3. 空気室内蒸発可能水分量のシミュレー ション結果と検討}

〈3.1〉 定数 $k$ の算出ならびに $d W(x) / d x$ と $d W_{3} / d x$ との関係 (5)式や $(7)$ 式の計算に当たって, 定数 $k$ を算出する必要がある。そこで, この定数を求めるに

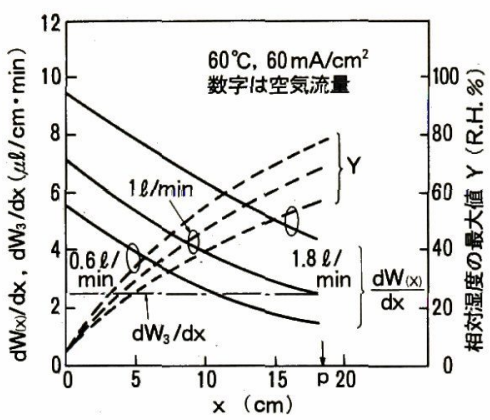

図 5 空気流路方向の距離 $x$ とその時点に おける生成水 $d W(x) / d x$ ならびに蒸発可能 水分量 $d W_{3} / d x$ との関係

Fig. 5. Relationships between $x$ and $d W(x) / d x, d W_{3} / d x$.

当たって，運転実績のあるセルにおいて空気流量 $Q_{N}$ が $1 \mathrm{l} / \mathrm{min}$ としたとき最も性能が良かった（この場合 $B=0$ としている) ことから，この条件から計算し， $0.01(\mathrm{l} / \mathrm{min} \cdot \mathrm{cm})^{0.5}$ が得られた。なお, 計算に当たっ ては特にことわらない限り電池は $60^{\circ} \mathrm{C}, 40 \mathrm{~mA} / \mathrm{cm}^{2} て ゙$, $25^{\circ} \mathrm{C}, 60 \% \mathrm{RH}$ の䨌囲気で運転する場合を標準とした。 この $k$ を用いて，運転実績のあるセルの $Q_{N}$ をパラメー 夕とした $x$ と $d W(x) / d x, d W_{3} / d x$ の関係を図 5 に

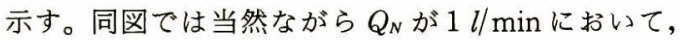
$x=p て ゙$ 曲線と一点鎖線が一致している。また，空気 室内で $W(x)$ が蒸発したときの相対湿度 $Y=C_{x} / C_{s}$ を見ると， $Q_{N}$ が小さいと湿度も高くなり， $Q_{N}$ が $1 \mathrm{l} / \mathrm{min}$ では空気室出口で約 $70 \% \mathrm{RH}$ になる。

ところで, 同図の $d W(x) / d x$ と $d W_{3} / d x$ を比較し た結果をまとめて次に示す。

まず，空気流量をセル当たり $0.6 \mathrm{l} / \mathrm{min}$ 送風した折 には, 空気室入口から中程までは $d W(x) / d x か ゙$ $d W_{3} / d x$ より大きく, 空気極の生成水を蒸発させても なお能力があまっている。しかし，この程度の状態で はメタノール極からの水分の補給で空気極が乾燥しな いように保たれるとみられる。ところが，空気室出口 付近では，生成水を蒸発できずに空気極に水分を残す こととなる。これを物理的に除去しないと水がたまり すぎて空気の浸入孔をふさぐことによって性能が不安 定になる可能性もでてくる。一方, 空気流量が 1.8 l min まで大きくなりすぎると, 空気極のどの場所でも 生成水の残留より蒸発能力が上回るので, メタノール 極からの水の補給が追いつかないと空気極が乾燥する こととなる。特に, 空気室入口付近ではそのような可 能性が大きい。空気流量が経験的に, $1 \mathrm{l} / \mathrm{min}$ 前後の ところで安定な性能を維持したことにより, $\Delta$ が 
$5 \mu / \mathrm{cm} \cdot \min$ 以下に保つよう空気流量を調節する必要 がありそうである。

\section{〈3・2〉 セル構造 $\boldsymbol{\Delta}$ との関係}

（1）電極面積 $S$ と $\Delta$ との関係 前節で算出し た $k$ 值を用いて，電極面積の違った場合のセルに対 して $\Delta$ と $Q_{N P}$ を計算した結果を図 6 に示す。同図に は燃料電池の運転で得られた $Q_{N P}$ の実測值も示した。 同図に示すように，dの寸法が違っているが電極面積 比較で $S$ が大きくなると $\Delta$ も大きくなるが， $d$ を大 きくすることで改良されることを示唆している。ま た，燃料電池の運転で性能が安定になるときの経験に よって得られた $Q_{N P}$ の実測值はほぼ計算值近傍にあ ることがわかる。

(2) 空気室奥行 $d$ と $\Delta$ との関係 空気室奥行 $d$ と $\Delta$ との関係について検討した一例を図 7 に示す。 同時に, 同図中には $Q_{N P}$ と $Y$ につても併記した。

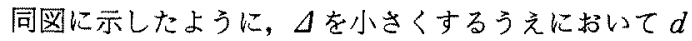
を大きくする効果の大きいことがわかる。このように $d$ を大きくすことによって，Aが小さくなるが $Q_{N P}$

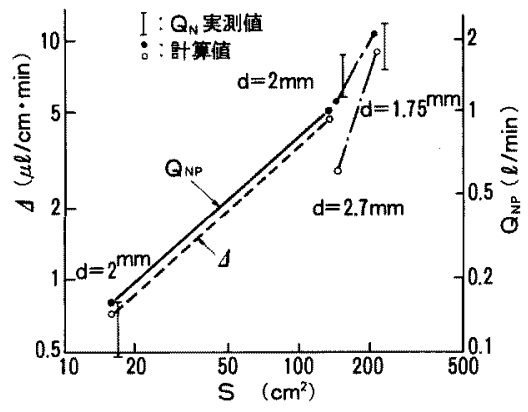

図 6 電極面積 $S$ と $\Delta, Q_{N P}$ との関係 Fig. 6. Relationships between electrode area and $\Delta, Q_{N P}$.

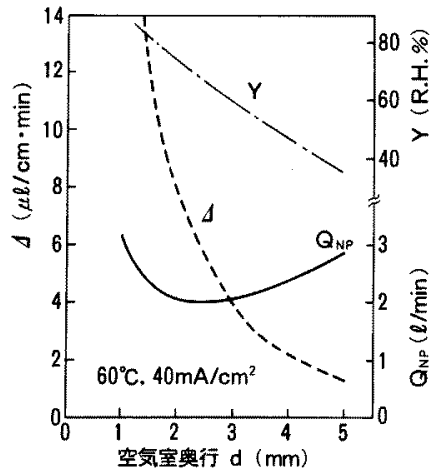

図 7 空気室奥行 $d$ と $\Delta, Q_{N P}$ との関係

Fig. 7. Relationships between air chamber depth and $\Delta, Q_{N P}$.
が上昇し，Yが低下していることからもかかるよう $に$, 空気室内で空気極から營気中への水分の蒸発効率 を悪くして $\Delta$ をさくしているためである。

$\langle 3 \cdot 3\rangle$ 定数 $B$ と $\Delta$ との関係 定数 $B$ は (2) 式 中の定数であるが，この值を変えた場合の $\Delta$ と $Q_{N P}$ を計算して図 8 に示す。同図に示すように, $B$ が大 きくなると $Q_{N P}$ がほとんど変わらないで $\Delta$ が小さく なることがわかる。このとき， $B=0$ の場合に比べ $\Delta$ が小さくなった分だけ水の蒸発が增えたとみることが できる。Bを大きくするには，電極触媒層を厚くして 保水量を增やすか，親水性をあげることなどが考えら れる。他の方法はイオン交換膜の水漫透抵抗の小さな 材料を選ぶことである。この場合には，水浸透抵抗を 小さくすることはメ夕ノールの透過係数を大きくする ことにもなり好ましくないので, 燃料電池のシステム として総合的に判断する必要がある。例えば，現在使 用しているイオン交換膜の場合, $B$ は $210 \mathrm{~cm}^{2} \cdot \mathrm{min} /$ $\mathrm{m} l$ であり，図 8 から見ると $B=0$ のときに比べ $\Delta$ が 40〜 50\%小さくなっている。

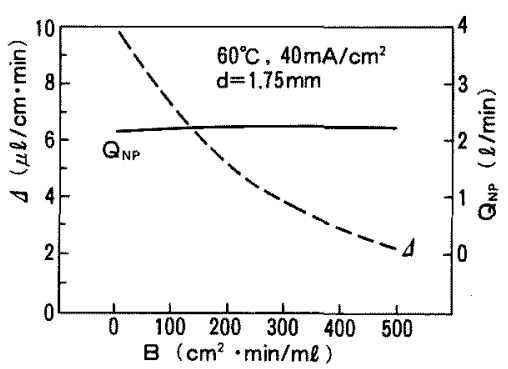

図 8（6)式におけるB值と $\Delta, Q_{N P}$ との 関係

Fig. 8. Relationships between $B$ value on Eq. (6) and $\Delta, Q_{N P}$.

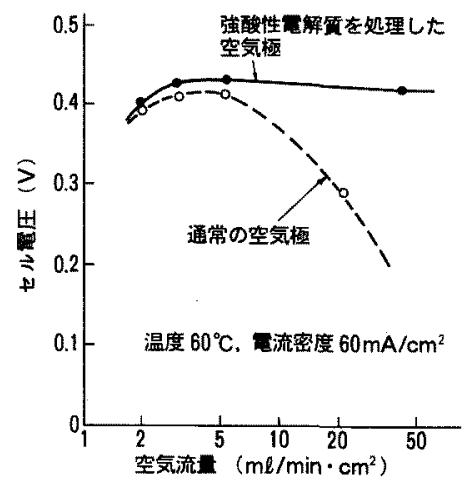

図 9 セル電压と空気流葍との関係

Fig. 9. Relationships between cell voltage and air flow rate.

T. IEE Japan, Vol. 112-B, No. 7, '92 
この $B$ を大きくする効果は, 空気室空気入口付近 の空気極が水不足の状態から，この不足の程度に応じ た水の浸透があり，水バランスを好適に保つ方向に作 用することにある。促って, 空気流路の下流測では水 の浸透が見られず，空気流量も多くすることなく を小さくできることになる。

漞水性を強化して性能安定性を示した実験結果を図 9に示す。すなわち, 空気極触媒層に強酸の電解質を 処理して親水性を強化したところ，空気流量の小さい ところは酸素不足となるため性能低下は否めないが, 触媒層の親水性の改善によって, 空気流量の大きなと ころまで空気流量の広い範囲にわたって性能が安定化 しており，その効果が想められる。

〈3.4〉運転条件と $\Delta$ との関係

(1) 雾囲気の変化と $\Delta$ との関係 雾囲気が変 わった場合の $\Delta$ を求めるにあたって, 雲囲気の変化 による空気室へ送風される空気中の水分 $W_{4}$ を然料電 池の運転温度である $60^{\circ} \mathrm{C}$ 相対湿度に換算した值で 示した。すなわち, 温度 $T$ に扔ける飽和水蒸気の密 度 $\sigma_{T}$ は次式で示される。

$$
\sigma_{T}=10^{5.652-2.175 \times 10^{3 /(273.15+T)} \quad(\mathrm{m} l / l)}
$$

従って，雲囲気の相対湿度を $\mathrm{RH}_{T_{1}}$ とすると，

$$
C_{0}=\frac{\mathrm{RH}_{T_{1}}}{100} \times \sigma_{T_{1}}
$$

$C_{S}=\sigma_{T_{2}}$ であるから，換算值 $\mathrm{RH}_{T_{2}}$ を導入した次式

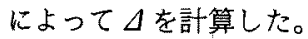

$$
\frac{C_{0}}{C_{s}}=\frac{\mathrm{RH}_{T_{1}}}{100} \frac{\sigma_{T_{1}}}{\sigma_{T_{2}}}=\frac{\mathrm{RH}_{T_{2}}}{100}
$$

計算結果の一例を図 10 に示す。同図には $Q_{N P}$ も示 した。同図に示すように，雲囲気の水蒸気分圧が増え る（あるいは調湿によって，空気室入口部で水分を供 給することでもよい)ことによって，ムが小さくなっ ており，性能安定化の改善効果が期待できる。しかし ながら，Q $Q_{N P}$ を大きくとる必要ができてくるので，む

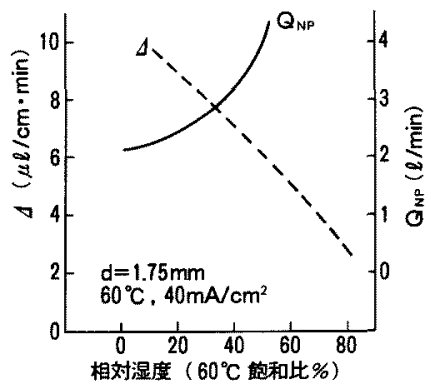

図 10 相対湿度と $\Delta, Q_{N P}$ との関係

Fig. 10. Relationships between relative humidity and $\Delta, Q_{N P}$.
やみに増すことはできない。

（2）燃料電池の電流密度, 温度変化と $\Delta$ との 関係 燃料電池の電流密度 $J$ が変わった場合の $\Delta$ を計算して図 11 に示す。電流密度が大きくなると， 図 2 に示したように空気極生成水が多くなるので，図 11 に示したように $Q_{N P}$ は增加する。

次に, 燃料電池温度 $T_{2}$ に対して $\Delta$ を計算して図 12 に示す。このときには，温度上昇と共にイオン交 換膜のメタノール透過係数は大きくなる(3)として を計算している。同図に示すように，温度上昇と共に $\Delta$ は増加するが， $Q_{N P}$ は減少している。 $Q_{N P}$ が隇少す るのは, 温度上昇にともない飽和水蒸気密度 $\sigma_{T_{2}}$ が大 きくなるためである。

〈3.5〉 考 察 燃料電池の安定な性能を維持 した運転にとって, 空気極の水バランスを好適に保つ ことが最も大切である。そのため, 空気極の生成水と これを送風空気中に蒸発させて排出する過程の計算を

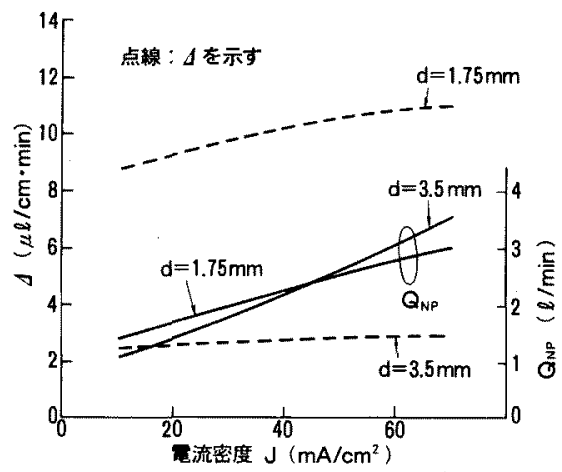

図 11 電流密度 $J$ と $\Delta, Q_{N P}$ との関係 Fig. 11. Relationships between current density $J$ and $\Delta, Q_{N P}$.

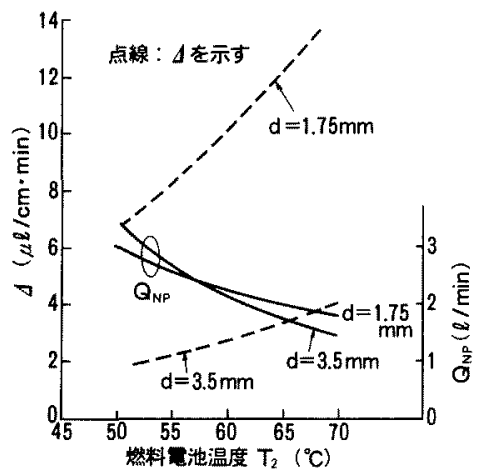

図 12 燃料電池の温度 $T_{2}$ と $\Delta, Q_{N P}$ との関係 Fig. 12. Relationships between temperature of fuel cell and $\Delta, Q_{N P}$. 
行った結果， $\Delta$ をさくする対策をとることが必要で あることがわかった。この対策として $d$ を大きくす るか， $B$ を大きくすることが最も効果がある。 $d$ を 大きくすることは, 前述のように構造が大きくなるこ とや空気流量が増えることもあって, その適用範囲に は制約がある。一方, $B$ を大きくするためには, 空気 極を厚くして保水量を増やすか, 図 9 の結果が示すよ うに電解質を付与して親水性を強化することである。 このことによって燃料電池の空気室空気流路方向の水 の拡散を良くして不均一を防止できる。他の対策とし て, イオン交換膜の水浸透抵抗を小さくしてメタノー ル極からの水の移動をよくすることもとりうるが, 同 時にメタノール透過係数も大きくなるので, そのバラ ンスが問題となる。前報で述べたように(8), 電解質層 として高分子固体電解質を用い硫酸を使わない燃料電 池に扔いてはイオン交換膜の水浸透抵抗が小さくな り，上記の目的が澾成される。

更に, 送風空気をあらかじめ調湿することも効果が みられる。しかし, 空気流量が増えることにもなるの で適用範囲に制限を受ける。

\section{4.むすび}

メタノール燃料電池の高効率で安定な性能を維持す るうえで, 空気極における水バランスを良好に保つこ とが不可欠である。そこで, 空気極における水の生成 と送風空気による水排出についての理論式を誘導し た。これを基に燃料電池の構造や運転条件が違った場 合のシミュレーションを行い, 水バランスを好適に保 つための対策を検討した。その結果得られた主な結果 を以下に示す。

（1）空気室の奥行を大きくすることは効果が大き いが，構造が大きくなることや空気流量が増えるので 適用範囲に限界がある。

（2）空気極を厚くし保水量を増やすか, 電解質を 付与して親水性を強化することも効果があり, 適用範 囲が広いので実用的である。

（3）イオン交換膜の水浸透抵抗を小さくすること も効果があり, 電解質層に高分子固体電解質を用い硫 酸を使用しないシステムではこれが達成される。た だ,メタノール透過量も増えるので燃料の濃度制御を 良くする必要がある。
その他, 燃料電池運転時の雲囲気の影響や電流密度 が変わった場合などについて解析した。

本論文は,メタノール燃料電池ばかりでなく他の燃 料電池においても，好適な運転に不可欠な設計上の諸 問題解決策を提起できたと考えている。

最後に, 本研究に対し種々御指導いただいた当所メ タノール燃料電池開発担当者各位に深謝いたします。

(平成 3 年 9 月 26 日受付)

\section{文献}

（1）津久井・田村：「液体燃料使用の燃料電池」, 電学誌, 104, 40 (昭 59-1)

(2) G. Ciprios: "The Methanol-Air Fuel Cell Battery", Intersociety Energy Conversion Engi. Conf., p. 9 (1966-11)

（3）津久井・土井・清水：「メタノール燃料電池の燃料利用率向 上法に関する考察」, 電学論 $\mathrm{B}, \mathbf{1 0 5}, 1033$ (昭 60-12)

（4）津久井・土井・清水:「メ夕ノール燃料電池の高効率運転方 法についての考察」, 同上 B, 107, 549 (昭 62-11)

（5）津久井・土井・雨川：「メタノール燃料電池の燃料消費量と 空気極の水バランスについての考察」, 同上B， 109, 299 (平元-7)

（6）化学ハンドブック編策委員会：化学ハンドブック, p. 696 (昭53) オーム社

（7）日本機械学会編：機械工学便覽，11（昭 35）日本機械学会

（8）津久井：「メ夕ノール燃料電池のメ夕ノール・水の消費量に 与える硫酸濃度の影響」, 電学論 $\mathrm{B}, 112,185$ (平成 4-2)

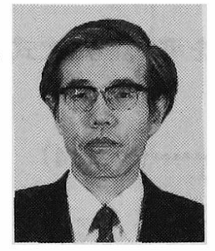

津久井

勤（正員）

昭和 13 年 2 月 22 日生。 36 年名古屋 工業大学電気工学科卒業。同年(株)日立 製作所入社。日立研究所において高電圧 絶緑の研究に従事。主として, 回転機用 コイル絶縁の開発を担当。その後, 放電応用機器, 燃料電 池の開発, 電子機器絶縁の信頼性の研究を担当し, 現在に 至る。工学博士。5 8 年電気学会論文賞受賞。電気化学協 会, プリント回路学会会員。

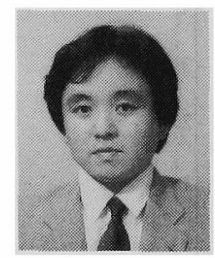

\section{朝 日 聖 隆 (非会員)}

昭和 39 年 9 月 30 日生。 62 年岩手大 学応用化学科卒業。同年(株) 日立機械工 ンジニアリング入社。入社以来, 燃料電 池の開発に従事し, 現在に至る。 